\title{
A Fraud Audit: Do You Need One?
}

Thomas Buckhoff, Georgia Southern University, USA

Leslee Higgins, Eastern Kentucky University, USA

Debra Sinclair, Georgia Southern University, USA

\begin{abstract}
This paper differentiates between a fraud audit and a financial statement audit and suggests that small businesses usually need a fraud audit although they engage a financial statement audit. A CPA trained in fraud examination and forensic accounting should conduct the fraud audit.
\end{abstract}

Keywords: Fraud, Audits, Forensic Accounting, Asset Misappropriation

\section{INTRODUCTION: SMALL BUSINESSES AND FRAUD}

(2)

mall businesses are especially vulnerable to fraud resulting from asset misappropriation. According to The 2008 Report to the Nation by the ACFE, organizations with fewer than 100 employees incurred median losses of $\$ 200,000$ due to asset misappropriation, which "was higher than the median loss in any other category, including the largest organizations." (ACFE, 2008, p. 5) Unfortunately, many small businesses who engage accounting firms to conduct an 'audit' mistakenly assume they are buying a fraud audit. This misunderstanding occurs mainly because accounting firms and their small business clients assume different definitions of fraud. When accounting firms think fraud, they typically assume financial statement fraud. When clients think fraud, they typically assume asset misappropriation. If a small business client's motivation for engaging auditors is because of concerns or suspicions involving asset misappropriation, it should specifically request a fraud audit.

For example, let's suppose that a small business owner (SBO) is concerned that the office manager, who has almost exclusive control over both cash receipts and cash disbursements, might be stealing from the organization. Accordingly, the SBO contacts an accounting firm to audit the company's books. The accounting firm sells the small business client a financial statement audit, which is not designed to uncover the type of fraud that is of primary concern to the SBO. The accounting firm completes the audit and issues a clean opinion that states that the financial statements present fairly the company's financial position and are in conformity with generally accepted accounting principles (GAAP). Two years later the SBO discovers that the office manager has stolen over $\$ 300,000$ from the organization. Consequently, the SBO is understandably upset with the accounting firm who did not detect the fraud that was ongoing at the time the audit was conducted. This article explains the two types of fraud along with the two types of audits businesses can purchase to detect and prevent it.

\section{A TALE OF TWO FRAUDS}

\section{Cardinal Wholesalers}

Bill Carter was a dangerous person for a company - an angry ex-employee in need of money. For 22 years, Carter had worked for Cardinal Wholesalers, a Fortune 500 company that manages a nationwide chain of grocery stores and had reached the level of purchasing department supervisor. ${ }^{1}$ But Carter had been fired for looking at inappropriate Web sites on his company computer. Out of work, in need of money, and angry with his former employer, Carter persuaded Mike Smith, Carter's replacement, to collude in perpetrating a fictitious vendor scheme against Cardinal. The purpose of this asset misappropriation scheme is to trick the victim company into paying

\footnotetext{
${ }^{1}$ This case is based on an actual investigation conducted by the lead author. The names of the victim company and the various players have been changed to protect their privacy. A detailed write up of the case can be obtained from the Center for Forensic Studies in Accounting and Business or from the April 2005 issue of Strategic Finance, pages 47-49.
} 
vendor invoices for which it receives nothing in return.

Five years into the scheme, Carter and Smith had each pocketed $\$ 900,000$. Carter then drank to excess one night at a local bar and foolishly bragged about the scheme to a total stranger sitting next to him. Carter explained in detail how he and Smith had stolen $\$ 1.8$ million from Cardinal and even divulged the name of the fictitious vendor, 'Tri-State Trucking.' The next morning the stranger called Cardinal and offered to sell the incriminating information for $\$ 250,000$ to Debbie Roberts, Cardinal's chief loss prevention specialist. Roberts refused the stranger's offer and hired Forensic Solutions, LLC--a forensic accounting firm.

After two days, the forensic accountants identified Tri-State Trucking as a suspicious vendor and interviewed Smith, who was the only person to approve payment on the dubious invoices. Smith admitted that TriState was a "bogus vendor" and that "the whole thing was Bill Carter's idea." The forensic accountants turned their investigative report and documentary evidence over to law enforcement. The FBI successfully charged and convicted Smith and Carter for mail fraud, which is a commonly used statute for prosecuting asset misappropriation cases. Carter was sentenced to 54 months in prison and was ordered to relinquish his $\$ 300,000401 \mathrm{~K}$ plan to Cardinal as restitution. In return for his guilty plea and testimony against Carter, Smith received 48 months in prison.

\section{WorldCom}

Long Distance Discount Services (LDDS) originated in Hattiesburg, Mississippi in 1983 and selected Bernard Ebbers to be its Chief Executive Officer (CEO) in 1985. LDDS went public in 1989 when it merged with Advantage Companies, Inc. During the next 11 years the company experienced three name changes as it purchased or merged with numerous other companies: LDDS WorldCom (1995), MCI WorldCom (1998), and WorldCom (2000). WorldCom eventually became the second largest long distance phone company in the United States, claiming over 20 million customers and reporting about \$36 billion in revenues in 2001.

In 1998, the telecommunications industry entered a downturn, making it difficult for WorldCom to achieve its ambitious growth and profit goals. According to court records, Mr. Ebbers then pressured his Chief Financial Officer, Scott Sullivan, to do whatever it took to achieve WorldCom's financial goals. Mr. Sullivan engaged other WorldCom employees to perpetrate a massive financial statement fraud, which primarily involved the following two methods:

1. Inflated revenues by $\$ 2.8$ billion by understating reserve accounts held to cover liabilities of acquired companies.

2. Inflated profits by $\$ 11$ billion by misclassifying 'line costs' as an asset instead of as an operating expense.

In 2002, Cynthia Cooper led a small team of WorldCom internal auditors in investigating and uncovering $\$ 3.8$ billion in fraudulent entries. WorldCom's audit committee and board of directors were then notified and acted quickly: Scott Sullivan (CFO) was fired, David Myers (Controller) resigned, Arthur Andersen (external auditor) withdrew its opinion, and the Securities and Exchange Commission launched an investigation. The ensuing negative publicity triggered the following chain of events:

1. WorldCom's stock price plummeted from a high of $\$ 64$ to pennies per share, stock trading was halted, and the NASDAQ delisted the stock in June 2002.

2. WorldCom filed for Chapter 11 bankruptcy protection in July 2002, which was the largest such filing in US history at the time.

3. WorldCom's collapse resulted in the loss of more than 17,000 jobs and billions of dollars in pensions and investments.

4. Five former WorldCom officials pleaded guilty to a variety of felony charges: Scott Sullivan, CFO; David Myers, Controller; Buford Yates, Accounting Director; and Betty Vinson and Troy Normand, both former accounting managers. 
Mr. Ebbers chose to go to trial where, on March 15, 2005, he was found guilty of all charges and convicted of securities fraud, conspiracy, and filing false documents with regulators. The 64-four-year-old Ebbers began serving a 25 year prison sentence in 2006 with a projected early parole date of July 4, 2028.

\section{QUESTIONS, QUESTIONS...}

Cardinal's external auditor - a large international accounting firm - did not discover the five-year-old asset misappropriation during the annual audits of the company's financial statements. WorldCom's external auditor, Arthur Andersen, did not discover the massive financial statement fraud that had collectively overstated profits by $\$ 13$ billion. The auditors' respective failures to detect these frauds raise the following questions:

1. Why didn't the auditors discover the frauds?

2. Should the auditors have discovered the frauds?

3. Who is responsible for detecting fraud? To answer these questions we must first: (1) define two types of fraud, (2) understand the objectives of a financial statement audit, and (3) understand the objectives of a fraud audit.

\section{Asset misappropriation vs. financial statement fraud}

Statement on Auditing Standard (SAS) No. 99, Consideration of Fraud in a Financial Statement Audit, describes two types of fraud: financial statement fraud and misappropriation of assets. SAS No. 99 defines financial statement fraud as "intentional misstatements or omissions of amounts or disclosures in financial statements designed to deceive financial statement users where the effect causes the financial statements not to be presented, in all material respects, in conformity with Generally Accepted Accounting Principles (GAAP)." This type of fraud, commonly referred to as 'cooking the books,' typically involves the overstatement of assets or revenues and/or the understatement of liabilities or expenses. Financial statement fraud is normally perpetrated by corporate executives whose compensation is closely tied to their employers' financial performances.

According to PricewaterhouseCoopers' 4th Biennial Global Economic Crime Survey of over 5,400 companies in 40 countries, $43 \%$ of companies reported average direct losses from fraud over two years of US $\$ 3.2$ million. In addition, $12 \%$ of companies reported having an "accounting fraud" problem ( $\mathrm{PwC}, 2007, \mathrm{p} .8)$. The 2008 Report to the Nation by the Association of Certified Fraud Examiners (ACFE) estimated that U.S. organizations lose $7 \%$ of their annual revenues to fraud, which translates to about $\$ 994$ billion in total fraud losses (ACFE, 2008, p. 4). About 10\% of reported frauds involved financial statement fraud, with annual median losses of US $\$ 2$ million (ACFE, 2008, p. 11). Only an estimated $9.1 \%$ of frauds were discovered by the external auditors (ACFE, 2008, p. 19). The WorldCom fraud perfectly exemplifies financial statement fraud.

Asset misappropriation (a.k.a. asset theft) entails the use of one's occupation for personal gain through the deliberate misuse or theft of the employing organization's assets. Asset misappropriation typically involves dishonest employees who have discovered a way to divert some of their employer's cash flow into their own pockets. According to PricewaterhouseCoopers' 4th Biennial Global Economic Crime Survey, 30\% of companies reported average direct losses from asset misappropriation over two years of US\$1.3 million (PwC, 2007, p. 8). According to The 2008 Report to the Nation by the ACFE, $89 \%$ of the 959 responding companies reported losses due to asset misappropriation, with annual median losses of US\$150,000. (ACFE, 2008, p. 11) The Cardinal Wholesalers' case is a perfect example of asset misappropriation.

\section{Fraud audits vs. financial statement audits}

The primary objectives of a fraud audit include: (1) examining the system of internal controls in place for safeguarding assets, (2) identifying any weaknesses in those controls, and (3) determining if anyone within the company has exploited the control weaknesses and misappropriated assets for personal gain. If properly planned and conducted, a fraud audit should uncover asset misappropriation. However, it is highly unlikely that a financial statement audit will uncover asset misappropriation. Why? Let's revisit the asset misappropriation scheme perpetrated against Cardinal Wholesalers. 
The fraudulent payments made to Tri-State Trucking were recorded by reducing the cash account by $\$ 1.8$ million and expensing the same amount on the income statement. Accordingly, the financial statements presented fairly Cardinal's financial position since both cash and net income had been reduced by the amount of the fraud. The only accounting error in this example is the income statement account that was used to expense the fraudulent payments. Instead of being debited to "transportation expense" the fraudulent payments should have been debited to "loss due to asset misappropriation," which — based on the prevalence of such fraud in business today - we would argue is a normal recurring operating expense. Therefore, the error is simply a misclassification of an operating expense, hardly a serious accounting sin. Moreover, the magnitude of the fraud, $\$ 1.8$ million over five years was clearly immaterial ${ }^{2}$ given that Cardinal's total revenues exceeded $\$ 1$ billion annually. Consequently, the external auditors correctly concluded that Cardinal's financial statements presented fairly, in all material respects, its financial condition. As explained earlier, the external auditors do not accept responsibility for detecting asset misappropriations since most of these frauds do not cause the financial statements to be materially misstated.

The primary purpose of a financial statement audit is to determine if a company's financial statements "present fairly" its financial position at a certain point in time. Investors, creditors, governments, and other stakeholders rely on financial statements for making economic decisions about a company. Since management is responsible for preparing the financial statements, someone independent of the company's management needs to vouch for the statements as being truthful and accurate. Such is the professional responsibility of the external auditors, who provide assurance that the financial statements: (1) conform to generally accepted accounting principles, and (2) present fairly, in all material respects, the company's financial position. If properly planned and conducted, a financial statement audit should uncover material financial statement fraud. If the auditors issue an opinion that the financial statements present fairly, when in fact they do not, they can be held civilly liable for any losses incurred by those who relied upon the misrepresented financial statements. Such liability was the downfall of Arthur Andersen, the external auditor for Enron, WorldCom, Sunbeam, Global Crossing, Qwest, and Waste Management - all of which were involved in financial statement frauds that resulted in billions of dollars in stakeholder losses.

\section{CONCLUSION}

In answer to the three questions posed earlier:

1. The external auditors did not discover the asset misappropriation presented in the beginning vignette because the fairness of the financial statements was not materially impaired by the fraud.

2. The external auditors should not have discovered the fraud since detecting asset misappropriation falls outside the scope of a traditional financial statement audit, which is designed to uncover material financial statement fraud.

3. The external auditors are professionally responsible for detecting material financial statement fraud, but not asset misappropriation fraud.

The accounting profession has not accepted responsibility for detecting fraud resulting from asset misappropriation, only that which causes the financial statements to be materially misrepresented, which most asset misappropriation schemes do not. A fraud audit, which is specifically designed to uncover asset misappropriation, is a separate engagement from a financial statement audit and requires auditing professionals with specific anti-fraud training and experience. The ideal fraud auditor should be a Certified Fraud Examiner (CFE) or be Certified in Financial Forensics (CFF). ${ }^{3} \quad$ Unfortunately, many clients who engage external auditors to conduct a financial statement audit mistakenly assume they are buying a forensic audit. Small businesses concerned about fraud losses resulting from asset misappropriation should specifically request a fraud audit instead of, or in addition to, a financial statement audit.

\footnotetext{
2 The annual amount of the fraudulent payments represented less than $.04 \%$ of total revenues.

${ }^{3}$ The CFF is a forensic accounting credential awarded by the American Institute of Certified Public Accountants (AICPA). For more information, go to http://www.aicpa.org/fvs.
} 


\section{AUTHOR INFORMATION}

Tom Buckhoff is an Associate Professor at Georgia Southern University. He teaches classes in fraud examination and forensic accounting. He conducts fraud examination engagements for his consulting firm.

Leslee Higgins is an Associate Professor at Eastern Kentucky University. She teaches in both the fraud examination area and the accounting information systems courses. She is the editor of the Journal of Forensic Studies in Accounting and Business.

Debra Sinclair is an Assistant Professor at Georgia Southern University. She teaches in the areas of financial accounting and forensic accounting. Her research interests are in the areas of fraud examination, corporate governance and pedagogy.

\section{REFERENCES}

1. Association of Certified Fraud Examiners (ACFE). 2008. Report to the Nation on Occupational Fraud and Abuse. Available at: http://www.acfe.com/documents/2008RttN.pdf

2. Eisenberg, Theodore and Jonathan R. Macey. 2003. Was Arthur Andersen Different?: An Empirical Examination of Major Accounting Firms' Audits of Large Clients. Cornell Law School Working Papers Series, Paper 14. The Berkley Electronic Press. Available at: http://lsr.nellco.org/cornell/clsops/papers/14.

3. Government Accountability Office (GAO), 2006. Financial Restatements -- Update of Public Company Trends, Market Impacts and Regulatory Enforcement Activities, July, page 12.

4. Huron Consulting Group, 2004 Annual Review of Financial Reporting Matters, http://www.huronconsultinggroup.com.

5. Marshall, A.G. and K. Raghunandan. 2001. Bankruptcies, Audit Reports, and The Reform Act, Auditing. Sarasota, March, Vol. 20. Issue 1, pp. 187 - 196.

6. Mayhew, Brian W., Jeffrey W. Schatzberh, and Galen R. Sevcik. 2001. The Effect of Accounting Uncertainty and Auditor Reputation on Auditor Objectivity. Auditing, September, Vol. 20. Issue 2, pp. 49 -70 .

7. Mills, D. Quinn. 2003. Wheel, Deal, and Steal: Deceptive Accounting, Deceitful CEOs, and Ineffective Reforms. Financial Times Prentice Hall. Upper Saddle River, NJ.

8. PricewaterhouseCoopers (PwC), 2007. The 4th biennial Global Economic Crime Survey. Martin-LutherUniversity, Economy and Crime Research Center. http://www.pwc.com/crimesurvey.

9. Toffler, Barbara Ley. 2003. Final Accounting: Ambition, Greed, and the Fall of Arthur Andersen. Broadway Books, a division of Random House, Inc.

10. Vafeas, Nikos. 2003. Length of board tenure and outside director independence. Journal of Business Finance \& Accounting. September. Vol. 30. Issue 7/8, pp. 1043-1064.

11. Wells, Joseph T. 2007. Encyclopedia of Fraud (2007 Edition). Association of Certified Fraud Examiners. 
NOTES 